Research, part of a Special Feature on Navigating tradeoffs

\title{
Balancing Development and Conservation? An Assessment of Livelihood and Environmental Outcomes of Nontimber Forest Product Trade in Asia, Africa, and Latin America
}

\author{
$\underline{\text { Koen Kusters }}^{1}, \underline{\text { Ramadhani Achdiawan }}^{1}$, Brian Belcher $^{1}$, and Manuel Ruiz Pérez ${ }^{2}$
}

\begin{abstract}
This article addresses the question, to what extent and under which conditions nontimber forest product (NTFP) trade leads to both livelihood improvement and forest conservation. We based the analysis on a standardized expert-judgment assessment of the livelihood and environmental outcomes of 55 cases of NTFP trade from Asia, Africa, and Latin America. The results show that NTFP trade benefits several components of peoples' livelihoods, but may increase inequality between households. Involvement of women in the production-to-consumption system (PCS) tends to have a positive impact on intrahousehold equity. In $80 \%$ of the cases, the commercial production of NTFPs does not enable people to make financial investments to increase quality and quantity of production, limiting the potential for development. In our set of cases, commercial extraction from the wild, without further management, tends to lead to resource depletion. NTFP production systems are generally considered to have lower environmental values than natural forest, but do contribute positively to the environmental values in the landscape. We found that higher livelihood outcomes are associated with lower environmental outcomes and conclude that NTFP trade is not likely to reconcile development and conservation of natural forest.
\end{abstract}

Key Words: assessment; conservation; development; environmental outcomes; forest use; livelihoods; livelihood outcomes; nontimber forest products; trade.

\section{INTRODUCTION}

In the early $1980 \mathrm{~s}$, the protectionist paradigm that had dominated nature conservation since the 19th century began losing ground. It was replaced by a strong notion among both conservationists and development practitioners that poverty reduction and environmental protection should go hand in hand (Adams 1990, Roe and Elliot 2004). In the following years several approaches emerged to reconcile development and conservation goals. The promotion of commercial nontimber forest product (NTFP) production, encompassing both extraction and cultivation, is one of these approaches (RosTonen et al. 2005).

NTFPs were given a prominent role in many conservation and development projects based on the proposition that supporting the production and trade of NTFPs leads to livelihood improvement without compromising the environment. That proposition was based on the following assumptions: (1) commercial NTFP production can provide economically attractive options to farmers helping to increase their income and offering development opportunities (Peters et al. 1989, Clay and Clement 1993); (2) NTFP production is a more benign way to use tropical forests than most land use alternatives, allowing for the conservation of key forest values (Myers 1988, Nepstad and Schwartzman 1992); and (3) increased monetary value of the NTFP will prevent people from converting the lands into other land uses (Evans 1993, Stiles 1994). Attracted by the potential for conservation and development, numerous scientists have studied NTFP production and trade. The evidence, however, remains inconclusive (see Neumann and Hirsch 2000, Arnold and Ruiz-Pérez 2001, Ros-Tonen and Wiersum 2005 for reviews). Although the extensive literature on NTFPs provides a good overview of the range of experiences, the lack of an extensive, comparable 
sample of cases studied with a common methodology has made it difficult to draw more general lessons.

To address that need, a recent multicollaborator project conducted comparative analyses of a broad range of cases of commercial NTFP production, processing, and trade, termed here production-toconsumption systems or PCS (Belcher 1998). NTFP was defined broadly to include woody products and cultivated products of forest origin. With the help of regional coordinators, the project selected a total of 61 cases, and researchers familiar with those cases, from Asia, Africa, and Latin America. Only cases that already had been studied were selected, representing a wide variety of products and systems. Elaborating on a methodology developed by RuizPérez and Byron (1999), two distinct datasets were collected. The first dataset includes standardized descriptors of the ecological, economic, social, and political characteristics of 61 PCS. These data provide a "snapshot" of the current situation, with some trend information. The approach to the development of this dataset is described in Belcher and Ruiz-Pérez (2001). Several products of the analysis are now available (e.g., Ruiz-Pérez et al. 2004, Belcher et al. 2005). The main lessons from the analysis are captured in a short video (http://ww w.cifor.org/publications/ntfpsite/docs/video.htm).

The second dataset was collected for a separate assessment of conservation and development outcomes of NTFP trade, based on expert judgment by the case researchers. The researchers responsible for the case studies assessed whether and to what extent the commercial trade of the product resulted in positive or negative effects on livelihoods and the environment.

This paper reports on the second exercise. It outlines the approach and the variables used, and analyzes the relationship among variables and among different groups of cases. This allows for an assessment of livelihood and environmental outcomes of NTFP trade and an analysis of the linkages between conservation and development. Furthermore, this analysis helps clarify the disparity of results with respect to the livelihood and environmental outcomes of NTFP trade found in the literature.

\section{METHODS}

We developed a methodology to assess livelihood and environmental outcomes, based on expert judgments. The aim was to identify the general direction and degree of changes that result from commercial nontimber forest product (NTFP) production and trade, based on existing knowledge. Although the cases were to be assessed by recognized researchers with a long experience working with their respective cases, it was accepted that any individual assessment will be subjective and may focus on some issues more than others, depending on the professional orientation, personal preferences, and actual experience with the case. In order to maximize the objectivity and the comparability, we designed two assessment tools to be used by the case researchers to make the individual assessments systematic, comprehensive, to help ensure that all important issues are considered, and consistent, such that different assessors familiar with the case would make similar assessments.

We used an iterative process to develop a set of indicators to capture the key changes resulting from commercial NTFP production and trade. We began by outlining the objectives and constraints of the assessment process and proposing a prototype set of indicators to all collaborators. These indicators were then challenged, revised, and refined with the input of scientists representing a wide range of disciplines and experience. This helped to prevent the disciplinary bias that is often reflected in indicator sets (Bossel 2001, Rigby et al. 2000). A full description of the methodology and the process by which it was developed is presented in Kusters et al. (2005).

\section{Livelihood indicators}

The livelihood part of the assessment considers whether and to what extent commercial NTFP trade has affected peoples' livelihoods. The hypothesis is that increasing trade of nontimber forest products provides income, employment, and other opportunities for poor rural people to improve their welfare (Peters et al. 1989, Clay and Clement 1993).

Following contemporary definitions of livelihoods that include nonfinancial aspects, we used the Sustainable Rural Livelihoods (SRL) framework (Carney 1998, DFID 2005) to guide the selection of 
indicators (Table 1). Accordingly, indicators were defined to capture changes in the five asset categories that form the main components of peoples' livelihoods, namely financial, physical, natural, human, and social assets. These five asset categories have been widely adopted as an organizing principle of peoples' livelihoods (Bebbington 1999, Bossel 2001, Campbell et al. 2001, Gottret and White 2001, Angelsen and Wunder 2003, Cramb et al. 2004).

Recognizing that outcomes are highly scale dependent, we designed indicators for three different scales. At the household level, we selected indicators to assess how the commercial production of the target species has contributed to household assets and equity within households. Here we focus on NTFP producers, i.e., the households involved in extraction or cultivation of the studied product. At the community level, indicators address the effects on overall community assets in the study area. At this level, we also assess the effect of commercial production on equity between households in a community, as changes may be positive for one group of stakeholders, while negative for another (Dove 1994, Ashley and Hussein 2000). Theoretically, a strong productionto-consumption system (PCS) might also contribute to economic performance at the national level through job creation and foreign exchange earnings. In most cases reviewed for this study, national level impacts were insignificant, so these data were not analyzed further.

In addition to the five asset categories, an equity component was added to assess whether the NTFP trade has led to differential access to assets, as well as empowerment of women. Table 1 shows the set of livelihood indicators used in the analysis.

The assessment of livelihood outcomes was based on a $10-y r$ period, with an indicative reference period of 1990 to 2000 . As there are often no baseline data regarding livelihood status, the assessment relies on the expert judgment of changes on indicators. The $10-\mathrm{yr}$ period was deemed sufficiently long to be able to observe changes, but short enough for the assessor to make reliable judgments of changes based on the information available. Changes that occurred before 1990 are not captured in the assessment. Each indicator was assessed according to the question: "Did commercial production of the forest product lead to changes in ...."

\section{Environmental indicators}

We expect two major kinds of ecological impacts from the harvesting and management of any biological resource. First is the impact on the species itself, with effects on population size and distribution, as well as on the genetic composition of the population as a result of selective harvesting, active selection, or deliberate genetic manipulation. Second is the impact on the broader ecosystem. Some of these effects come directly from the actions of harvesting and management. Potentially much more important is the influence of decisions about overall land use. One of the arguments to support NTFP commercialization is that increased revenue flows from the standing forest can justify maintaining forest cover (Evans 1993).

We selected indicators to assess the sustainability of extraction, the environmental value of the NTFP land use system, and the extent to which the product influences peoples' land use decisions. There may be negative consequences of extraction that are unknown such as genetic impacts of selective harvesting and that are therefore not reflected in the assessment. Because ecosystem properties differ according to spatial scale (Hoekstra et al. 1991, Allen and Hoekstra 1992) and management outcomes can diverge between scales (Gottret and White 2001, Ticktin 2004), we selected indicators at three levels. The "target-species population level" refers to the population of NTFP species on which the case study has focused in the particular study area. The "land-use ecosystem level" refers to the zone within the study area in which the NTFP target species is produced. This can, for example, be a certain area of secondary forest, or the area in the study site that is covered with agroforest gardens. The "regional landscape level" refers to the study area, generally encompassing a mosaic of land uses, including settlements, agricultural lands, and forested lands. The selected indicators for each level are presented Table 2 .

At the population and land-use ecosystem level, the assessors compared the current situation with two hypothetical alternatives: (1) undisturbed mature natural, nonplanted forest, typical of the location; and (2) the most likely land-use alternative, i.e., the land use that would most likely occur if the NTFP target species had no commercial value. At the regional landscape level we did not compare with alternative scenarios. Here the researchers were asked to value whether the NTFP land use has a 
Table 1. Livelihood indicators at household and community levels.

\begin{tabular}{|c|c|c|}
\hline Asset & Household level indicators & Community level indicators \\
\hline Natural & $\begin{array}{l}\text { - } \\
\text { - } \quad \text { Legysical access to the target resource } \\
\text { - Control over the target resource }\end{array}$ & - $\quad$ Target resource stock \\
\hline Physica & $\begin{array}{l}\text { - } \quad \text { Shelter and household possessions } \\
\text { - } \quad \text { Means of transportation } \\
\text { - Ownership/access to production and } \\
\text { processing equipment }\end{array}$ & $\begin{array}{l}\text { - } \quad \text { Local infrastructure } \\
\text { - } \quad \text { Communication facilities }\end{array}$ \\
\hline Human & $\begin{array}{ll}\text { - } & \text { Health and nutritional status } \\
\text { - } & \text { Endogenous, i.e., "traditional," skills } \\
\text { - } & \text { Exogenous, i.e., "modern," skills } \\
\text { - } & \text { Access to information }\end{array}$ & - $\quad$ Effective community organization \\
\hline Financi & $\begin{array}{l}\text { - } \\
\text { - } \\
\text { - } \\
\text { - } \\
\text { Housularizing incomold savings } \\
\text { Access to credit }\end{array}$ & $\begin{array}{l}\text { - } \quad \text { Community financial resources } \\
\text { - } \quad \text { Access to employment }\end{array}$ \\
\hline Social & $\begin{array}{l}\text { Endogenous social resources, i.e., cohesion } \\
\text { and confidence } \\
\text { - } \quad \text { Exogenous social resources, i.e., contacts } \\
\text { and bargaining power } \\
\text { - Political power }\end{array}$ & $\begin{array}{l}\text { - } \quad \text { Socio-cultural cohesion } \\
\text { - } \quad \text { Leverage with outside agents }\end{array}$ \\
\hline Equity & $\begin{array}{l}\text { Equitable access to the target resource } \\
\text { within household } \\
\text { Equitable access to physical assets within } \\
\text { household }\end{array}$ & $\begin{array}{l}\text { - Equitable access to forest resources within the } \\
\text { community } \\
\text { Equitable physical access to the target species } \\
\text { within the community }\end{array}$ \\
\hline
\end{tabular}


Table 2. Environmental indicators.

\begin{tabular}{lll}
\hline \hline Level & Indicators \\
\hline Target species population level & $\bullet \quad$ Changes in population size \\
& $\bullet \quad$ Changes in distribution, i.e., range \\
& $\bullet \quad$ Changes in population structure, e.g., sex and age ratio
\end{tabular}

Land-use ecosystem level

- Changes in forest species diversity

- Changes in soil structure

- Changes in soil pollution levels

Regional landscape level

- Role as a reservoir of forest species

- Role as a biodiversity corridor

- Role in erosion control and hydrology

- Role in pollution

significant impact on environmental conditions in the study area. For example, the outcome for the indicator "reservoir of forest species" is positive when the NTFP land use system preserves biodiversity existing in the study area.

\section{Implementation and analysis}

Researchers were asked to rate the outcomes for each indicator in their case on a five-point ordinal scale: very negative (-2), negative, neutral, positive, and very positive $(+2)$. Assessments were mostly done in group exercises in the regions, with researchers assessing their own cases and discussing the process and the results. This was effective for stimulating discussion, facilitating consistent and comparable interpretation, and scoring of the indicators. We acquired complete assessments for
55 cases: 17 from Africa, 21 from Asia, and 17 from Latin America (see Appendix 1).

In the analysis, the indicators were all treated as having uniform weight. We explored the relationships among livelihood indicators, among environmental indicators, and across the two sets of indicators using Spearman rank correlation tests, Kruskal-Wallis nonparametric tests and multivariate principle component analyses. We explored the relationship between the outcomes and five NTFPrelated livelihood strategies, following the typology developed by Belcher et al. (2005) on the basis of the analysis of the descriptive variables.

The five distinctive groups of cases identified by Belcher et al. (2005) are each characterized by the role of the NTFP in the household economy. The groups are: 
- Subsistence group: The NTFP contributes little to the total household income, i.e., cash and subsistence, but is the main or the only source of cash income. Cases are situated in remote areas, and the product is often extracted from de facto, open-access lands.

- Supplementary group: The NTFP contributes less than $50 \%$ to the total household income, and the households are well integrated into the cash economy. The NTFP is collected from the wild and supplements the household's income, often at times when other sources of income are low.

- Integrated group: Similar to the supplementary group, the NTFP contributes less than $50 \%$ to the household's cash income, and households are well integrated into the cash economy. In the integrated group, however, the product is cultivated and integrated into a diverse set of income earning activities. Production is predominantly on private lands and markets are mostly local.

- Specialized extraction group: The NTFP contributes more than $50 \%$ to the household's income, and the households are well integrated into the cash economy. The product is harvested from the wild, is often of high value and traded nationally or internationally.

- Specialized cultivation group: The NTFP species is cultivated in intensive systems and contributes more than $50 \%$ to the household's cash income. Integration into the cash economy is high. Cultivation is mostly on private lands, and markets tend to be international.

Each group showed clear patterns of relations with a wide range of other variables in the data set
(Belcher et al. 2005). We therefore used the typology as entry point to explore which case characteristics are associated with different types of outcomes. The main characteristics of the household strategies are summarized in Table 3. Though all categories are found in all three regions, African cases tend to fall in the subsistence category, whereas the specialized categories are relatively common among the Asian cases. These patterns are indicative of broader regional features, i.e., the relatively poor conditions in Africa, and the existence of better-developed markets in Asia. Lastly, it should be noted that the sample of cases that we studied does not provide a truly random sample of all NTFPs. Still, the methodology, in combination with a large enough data set, allows good comparability of general changes as a result of commercial production.

\section{RESULTS AND DISCUSSION}

\section{Livelihood outcomes}

Overall, the assessments show that nontimber forest product (NTFP) trade has a positive impact on local livelihoods (Fig. 1). Financial, human, physical, and social assets, the conventional development indicators, are well above the neutral line (0), with a very low occurrence of negative scores. Equity is positive, though with a lower average and with $24 \%$ of cases having negative scores. The average score for natural assets is neutral, with $42 \%$ of cases showing a reduction in access to natural assets, i.e., negative score. In the livelihood outcomes analysis the term "natural assets" only relates to the target resource. The high standard deviation for this asset group implies a large variability among cases in the response to commercial NTFP production.

There has been a rich theoretical discussion about the multiple components of livelihoods, and the Sustainable Rural Livelihoods (SRL) framework explicitly disaggregates them. In our cases the components are indeed differentiated, but there is a very strong positive correlation between financial, social, human, and physical assets (Table 4), with the financial assets typically scoring highest. The score on the equity component is associated with human and social assets, but independent of financial and physical assets. Scores on natural asset indicators are correlated with equity outcomes, and 
Table 3. A typology of nontimber forest product- (NTFP) related household strategies: dominant characteristics based on Belcher et al. (2005).

\begin{tabular}{lccccc}
\hline \hline Household strategy & Subsistence & Supplementary & Integrated & $\begin{array}{c}\text { Specialized extra- } \\
\text { ction }\end{array}$ & Specialized cultivation \\
\hline $\begin{array}{l}\text { Percentage of cases } \\
\text { (N=55) }\end{array}$ & $27 \%$ & $36 \%$ & $16 \%$ & $13 \%$ & $7 \%$ \\
$\begin{array}{l}\text { Contribution of NTFP to } \\
\text { income* }\end{array}$ & $<50 \%$ & $<50 \%$ & $<50 \%$ & $>50 \%$ & $>50 \%$ \\
$\begin{array}{l}\text { Integration in cash } \\
\text { economy** }\end{array}$ & $<50 \%$ & $>50 \%$ & $>50 \%$ & $>50 \%$ & $>50 \%$ \\
$\begin{array}{l}\text { Cultivation } \\
\text { Land tenure }\end{array}$ & No & No & Yes & No & Yes \\
Product value & State or communal & Private & $\begin{array}{c}\text { State or } \\
\text { communal }\end{array}$ & Private \\
Market & Local & Medium & Medium & High & High \\
& Regional & Local & $\begin{array}{l}\text { National and } \\
\text { international }\end{array}$ & $\begin{array}{c}\text { National and } \\
\text { International }\end{array}$ \\
\hline
\end{tabular}

* Cash and subsistence household income

** Percentage of total income received as cash

independent of the rest. Financial assets are thus related to all asset groups, except the natural assets and equity. There are no negative correlations between the scores of the various livelihood components.

Classifying the cases according to the five NTFPrelated livelihood strategies presented in Table 3, results in some strong patterns. All classes show positive mean livelihood scores, but there are important variations in the absolute and the relative contributions of the different components (Fig. 2). Most notably, the mean score for natural asset indicators is negative for the subsistence and specialized extraction household strategies (Table $5)$. These livelihood strategies are based on harvesting from the wild, which tends to result in resource depletion. Though the supplementary strategy is also based on harvesting from the wild, this group has a neutral mean score for the natural asset indicators, because it contains several cases where the resource is being managed to protect or stimulate growth. The integrated and specialized strategies based on cultivation show positive scores on the natural asset indicators.

Some of the indicators in particular are indicative of the development potential of NTFP trade in a particular case.

- A positive score on the "ownership or access to production and processing equipment" indicator suggests that the production-toconsumption system (PCS) is profitable enough to attract investment and that the stakeholders have sufficient resources to invest. Only the specialized cases, i.e., $20 \%$ of the total, have such a positive score, suggesting that the means and/or the opportunity for reinvestment in the sector are insufficient in the other cases. 
Fig. 1. Aggregated mean outcomes of the different livelihood components. The bars represent the mean and the lines represent the standard deviation. The percentage of cases with a negative mean score is presented in brackets.

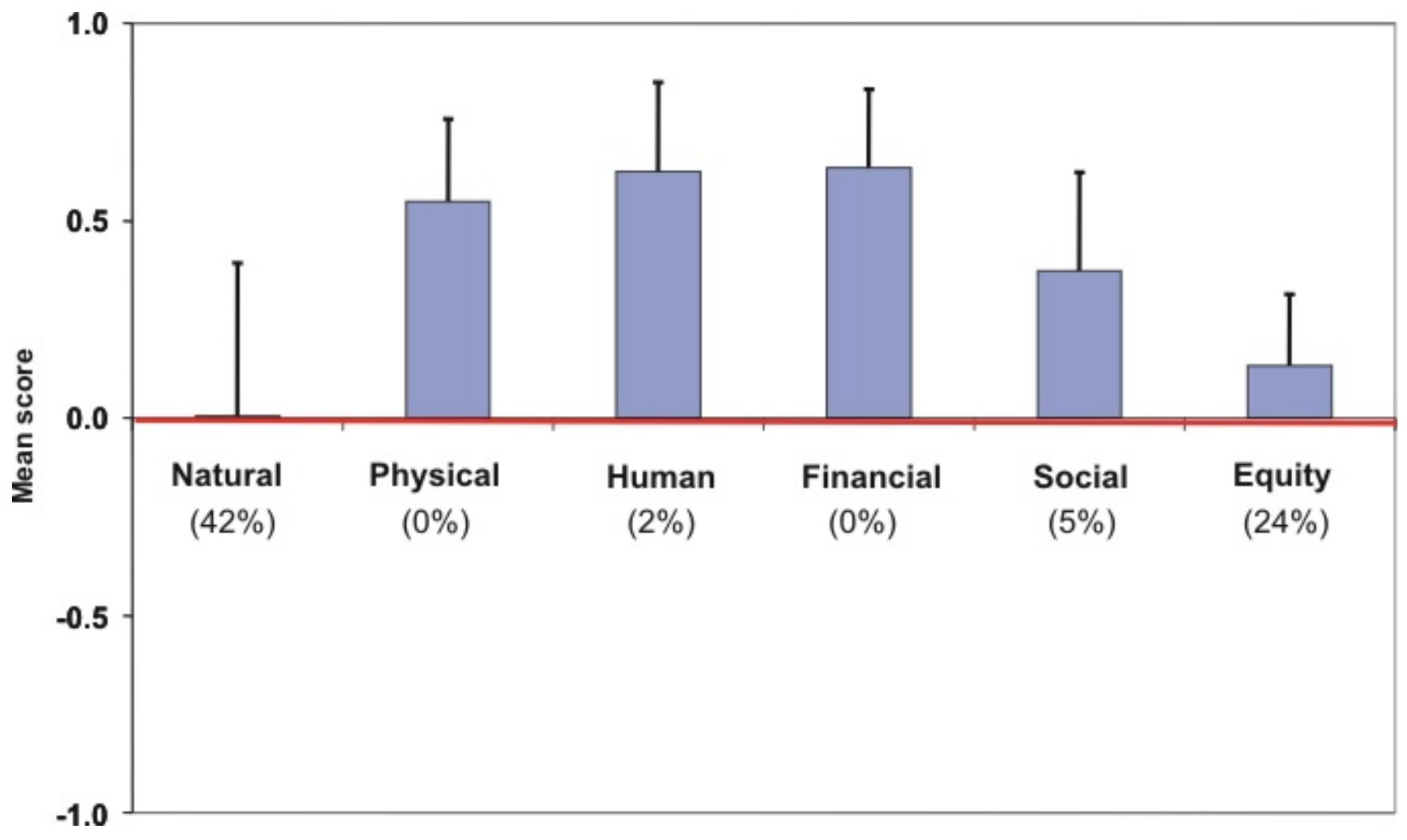

- The "changes in local infrastructure" indicator was constructed to capture community spin-off effects. A common assumption in strategies to promote NTFPbased enterprise development is that it will benefit the community as a whole when collective income from NTFP trade, e.g. through taxes or community funds, is invested in community infrastructure. We found the highest average score for this indicator in the group of subsistence cases, in which community financial resources depend to a relatively large extent on cash generated through NTFP sales, often the main or only source of cash income.
- A positive score on the "access to information" indicator may also have important development spin-offs. In $62 \%$ of the cases, NTFP trade leads to improved access to information, often as a result of increased interaction with traders. This may contribute to improved trade, e.g. improved market information, as well as to more general livelihood improvements as people learn and apply new knowledge.

The livelihood outcomes scores at the household level are consistently higher than at the community level (Fig. 3). Community benefits tend to be secondary to those at household level and are often indirect. Equity within the community is negatively affected in $25 \%$ of the cases in which some households gain from trade opportunities while 
Table 4. Correlation coefficients of aggregate livelihood outcomes.

\begin{tabular}{lllllll}
\hline \hline Component & Natural & Physical & Human & Financial & Social & Equity \\
\hline Natural & 1.000 & & & & \\
Physical & 0.090 & 1.000 & & & \\
Human & 0.121 & $\mathbf{0 . 6 6 7 * *}$ & 1.000 & & \\
Financial & 0.180 & $\mathbf{0 . 7 9 0 * *}$ & $\mathbf{0 . 7 0 5 * *}$ & 1.000 & \\
Social & 0.209 & $\mathbf{0 . 5 0 5 * *}$ & $\mathbf{0 . 6 4 1} * *$ & $\mathbf{0 . 4 0 2 * *}$ & 1.000 & \\
Equity & $\mathbf{0 . 3 7 0 * *}$ & 0.261 & $\mathbf{0 . 4 0 1}$ & 0.173 & $\mathbf{0 . 4 5 0 * *}$ & 1.000 \\
& & & & & & \\
\hline
\end{tabular}

others do not, or even lose access to the resource. The cases characterized by specialized extraction from wild products, i.e., the specialized extraction group, in particular tend to have negative outcomes for interhousehold equity. This group also has the largest difference between mean household and community outcomes (Fig. 3), reflecting the importance of niche specialization both to promote development but also to increase inequality. In line with this, cases with increasing differences between households tend to have negative outcomes for sociocultural cohesion between households (ChiSquare $_{\mathrm{df} 2}=6.227 ; P$-value $\left.=0.044\right)$.

Intrahousehold equity improved in about half the cases. This is correlated with the involvement of women in the PCS (Chi-square $_{\mathrm{df} 2}=6.8 ; P$-value $=$ 0.032 ). This involvement provides opportunities for women to engage in the cash economy, strengthening their position in the household. There is also a positive correlation between women's involvement and the "endogenous social resources" indicator at the household level, reflecting social cohesion and confidence within the household (Spearman rank correlation coefficient $=0.255 ; P$ value $=0.060)$.

\section{Environmental outcomes}

There are much greater differences in the environmental outcomes than in the livelihood outcomes, and there is much greater variability between the various environmental indicators across cases (Fig. 4). The mean score at the target species population level, i.e., three indicators, is close to neutral but more than $40 \%$ of the cases experienced resource depletion. This is consistent with the natural asset outcomes in the livelihood assessment.

In order to have a reference point for the environmental outcomes assessment, it is important to identify the most likely land-use alternative. In most cases where the product is collected from the wild, the harvesters do not have control over the land use, and/or the product is not valuable enough to influence the land-use choice. In these cases, the alternative land use is therefore the same as the current land use, but without commercial extraction of the product. In cases in which the target species is being cultivated, the land-use choice does depend on the value of the product; if the product had no commercial value, managers would use the land differently. In most cases, the NTFP ecosystem is considered to perform environmental functions better than the most likely alternative land use, usually intensive agriculture, but worse than a hypothetical natural forest alternative. At the 
Fig. 2. Aggregated mean livelihood outcomes of different household strategies. The bars represent the mean and the lines represent the standard deviation. The star diagrams in the lower half of the figure present the relative contributions of different livelihood components to the aggregated mean. A red arrow indicates a negative average.

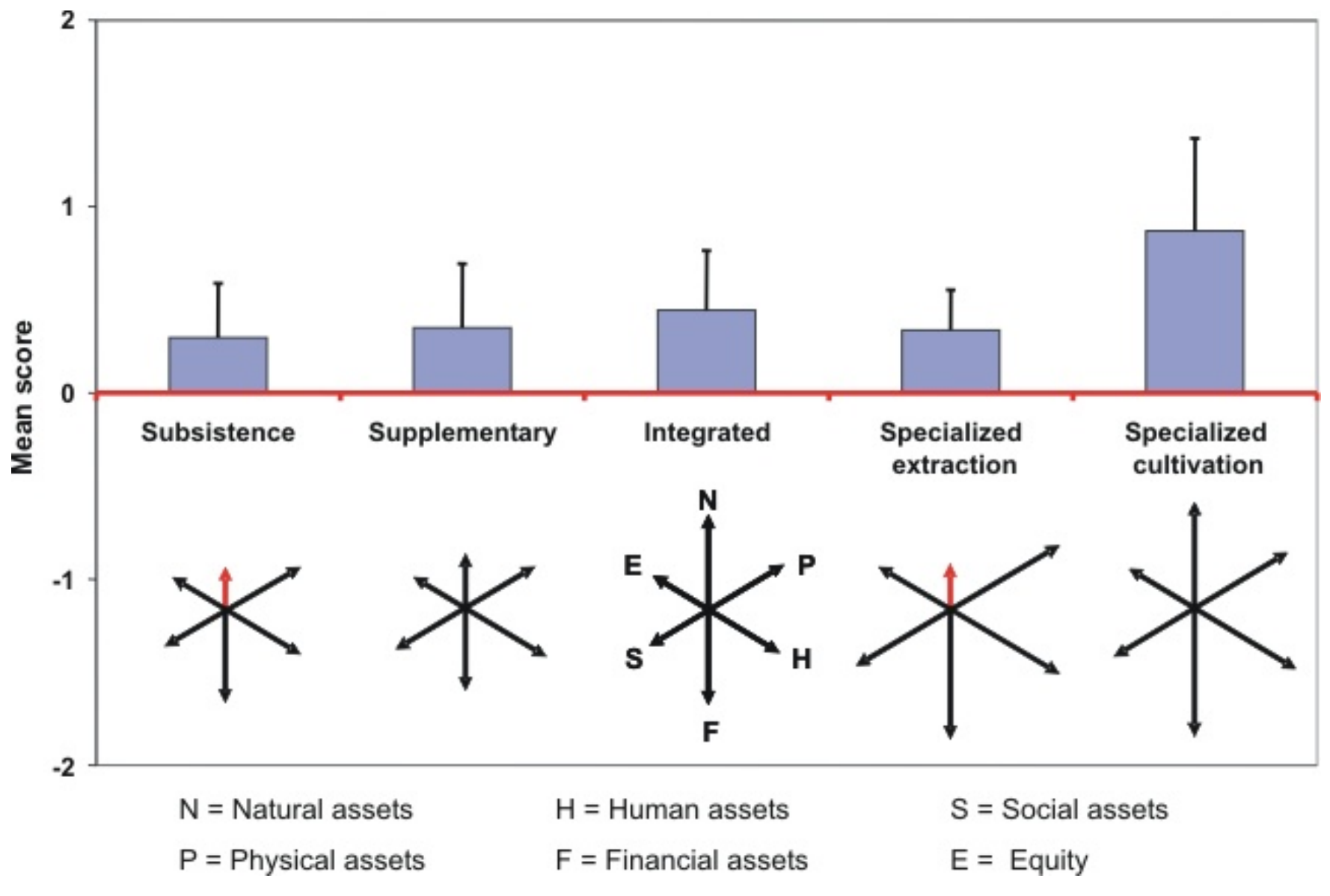

landscape scale most cases were assessed to have a positive impact, with only $5 \%$ having a negative outcome (Fig. 4).

As with the livelihood outcomes assessment, we analyzed the environmental outcomes for each of the NTFP-related household strategies. Unsurprisingly, the effect of harvesting on the target species population is generally positive when the product is cultivated, and negative for the other cases. Cases in which households have specialized in extraction from the wild have the most negative mean outcome, indicating a high impact of harvesting activities on the species' population (Fig. 5, upper left panel).
As discussed above, the assessment of outcomes at the ecosystem scale depends on the benchmark used. The upper right panel of Fig. 5 shows the mean scores when the environmental functions of the NTFP production system are compared to those of the natural forest. The functions of the production systems in the subsistence group tend to be similar to those in natural forest. The production systems in the specialized cultivation group, on the other hand, are the least similar to natural forest. The outcomes are different at the landscape scale (Fig. 5, lower left panel). Remarkably, the specialized cultivation group has higher outcomes than the specialized extraction group. This indicates that more intensive NTFP management typically occurs 
Table 5. Mean aggregate livelihood outcomes per household strategy. I = Subsistence; II = Supplementary; III = Integrated; IV = Specialized extraction; V = Specialized cultivation .

\begin{tabular}{lrrrrrrc}
\hline \hline & \multicolumn{3}{c}{ Mean } & \multicolumn{2}{c}{ Kruskal-Wallis test } \\
\hline Indicators & I & II & III & IV & V & Chi-Square & $P$ \\
Natural assets & -0.3 & 0 & 0.7 & -0.7 & 0.9 & 19.95 & 0.001 \\
Physical assets & 0.5 & 0.4 & 0.5 & 0.7 & 1 & 4.47 & 0.346 \\
Human assets & 0.5 & 0.6 & 0.5 & 0.7 & 1.1 & 5.71 & 0.222 \\
Financial assets & 0.6 & 0.5 & 0.6 & 0.8 & 1.2 & 11.81 & 0.019 \\
Social assets & 0.3 & 0.4 & 0.2 & 0.5 & 0.7 & 2.35 & 0.671 \\
Equity & 0.1 & 0.1 & 0.2 & 0 & 0.4 & 1.36 & 0.852 \\
& & & & & & & \\
\hline
\end{tabular}

in more developed areas dominated by agriculture or other intensive land uses. Thus, even though an intensively managed NTFP production system has low environmental values when compared to the natural forest, it may still provide some important environmental benefits of a forest ecosystem.

In the integrated and specialized cultivation groups in which people tend to have control over their lands, the value of the product may prevent people from converting the lands to uses with less environmental functions (Fig. 5, lower right panel). However, with intensified production, the system becomes increasingly similar to intensive agriculture or horticulture.

\section{Development and conservation}

So far, we have analyzed the livelihood and environmental outcomes independently. Below, we will explore the relationship between the development and conservation outcomes. Again classifying the cases by household strategy, we consider the outcomes for development, defined as increasing access to financial, physical, social, and human assets, and the outcomes for conservation, defined as the maintenance of natural forest functions in tandem (Fig. 6). The extent to which a NTFP system maintains natural forest functions is based on the scores of the comparison of environmental functions of the NTFP ecosystem with those of natural forest. As a general trend, the development scores are high when households specialize, whereas conservation scores are high when the product is collected from the wild. The specialized extraction group seems to represent the most balanced relation between development and conservation. When we consider the various household strategies as different stages in the development process, starting with the subsistence strategy and with the specialized cultivation strategy as the highest stage, the trend lines in Fig. 6 suggest that the development process leads to a decrease of natural forest functions.

For a more nuanced analysis of the relationships between the different environmental and livelihood outcomes we used principal component analysis (PCA, Fig. 7). For this analysis we excluded the population level from the environmental outcomes, as changes in target resource base are covered under natural assets. Financial, human, physical, and social assets are strongly correlated, and financial assets serve as the most indicative component of livelihood outcomes. Environmental functions at the land-use ecosystem and landscape scales are strongly opposed to the main livelihood outcomes. This means that cases with relatively high outcomes for environmental functions at the ecosystem and landscape level tend to have relatively low outcomes for conventional development (cf., 
Fig. 3. Mean scores of livelihood indicators at the household level vs. the community level.

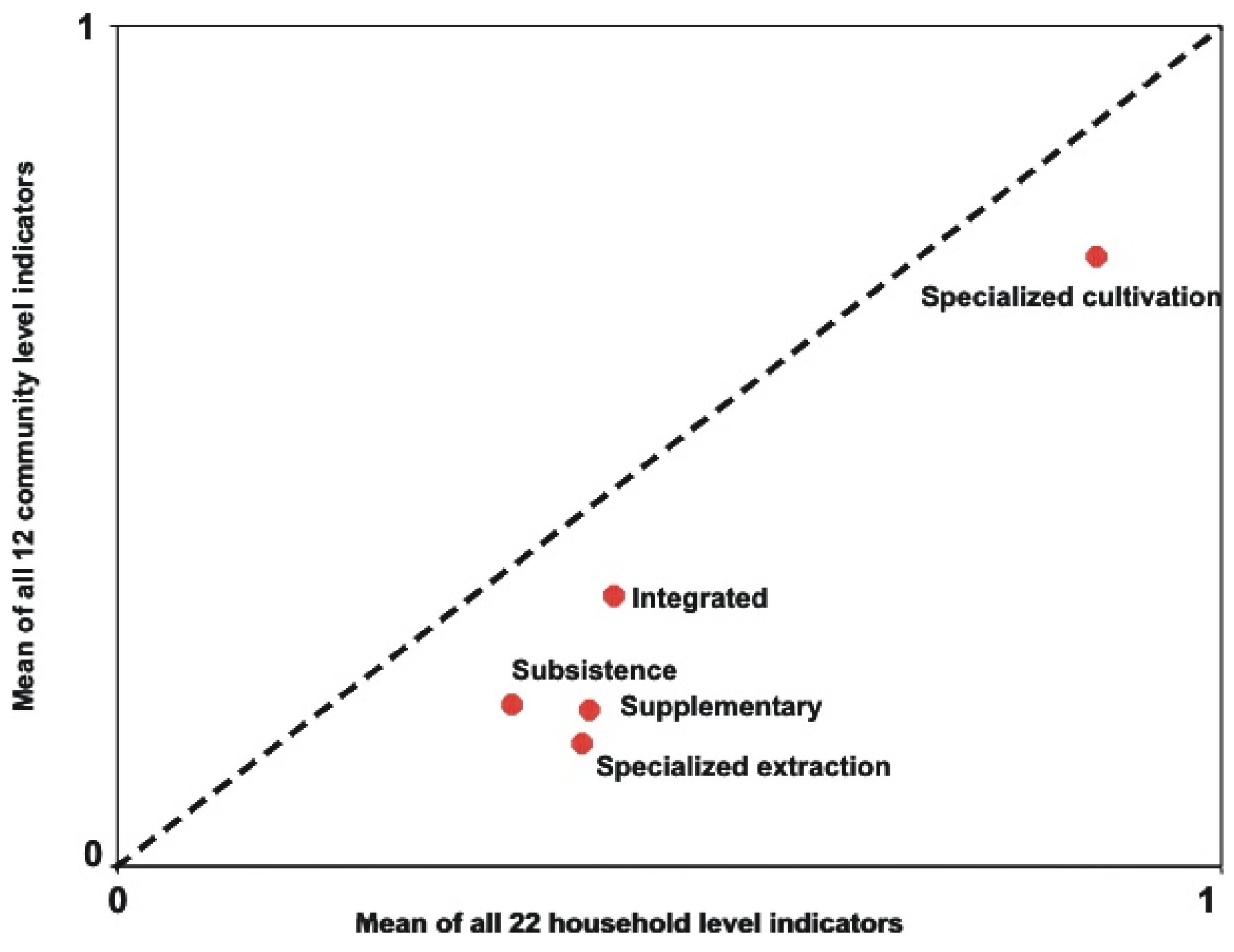

Levang et al. 2005). Natural assets and, to a lesser extent, equity represent orthogonal, independent dimensions, as already discussed.

The PCA also allows us to address the relations between the outcomes and the household strategies. The specialized cultivation cases are characterized by relatively positive outcomes on livelihood assets. Groups pursuing subsistence, supplementary and integrated strategies are characterized by positive outcomes for environmental indicators at the ecosystem and landscape scale, but relatively low livelihood outcomes. Whereas in Fig. 6 the specialized extraction group stood out as having relatively high scores for maintenance of natural forest functions, Fig. 7 shows that this group of cases is mostly characterized by low outcomes for access to natural assets, suggesting highly unsustainable production systems due to rapid depletion of the target resources. By looking at individual cases, we found that specialized production through cultivation of NTFPs in an agroforestry system offers the best compromise, yielding generally positive livelihood and environmental outcomes. 
Fig. 4. Aggregated mean environmental outcomes. The bars represent the mean and the lines represent the standard deviation. The percentage of cases with a negative mean score is presented in brackets.

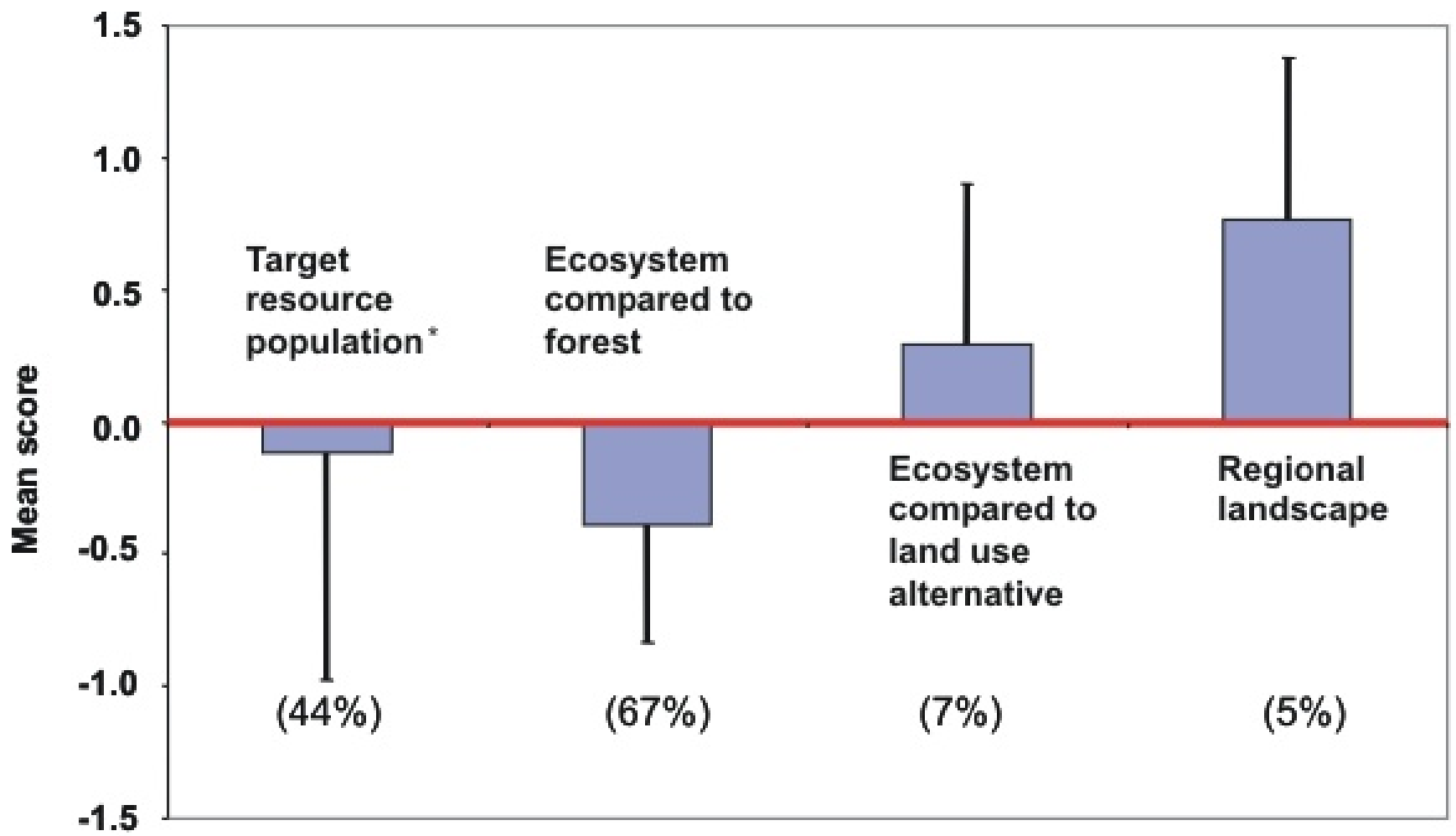

*At the level of the target resource population the current situation was compared with the natural forest and the land-use alternative. The scores for both assessments were similar, and we therefore present the aggregate score.

\section{CONCLUSIONS}

A general understanding of the potential of nontimber forest product (NTFP) trade for conservation and development has been hampered by the lack of comparative studies using a common approach. Our methodology was designed to fill this gap, by assessing livelihood and environmental outcomes of a large number of cases of NTFP trade, based on expert judgment, and using simple indicator sets. Though such a method unavoidably subsumes details, and depends on case selection, the method proved useful to produce generalizable results regarding relations between the types of cases, i.e., characteristics, and types of outcomes.
Almost all cases were assessed to have positive livelihood outcomes. This is logical considering that, by definition, there is a commercially viable trade, one of the criteria for case selection, and so each of the cases evaluated is providing income, employment opportunities and other benefits. The financial benefits are unequivocally positive, but in a few cases commercial production had negative social impacts, nearly $25 \%$ of the cases had negative equity impacts, and more than $40 \%$ had negative impacts on the natural assets.

Although it is without a doubt that these benefits are important in their context, often with very limited alternatives, most of the production to consumption systems (PCSs) assessed fail to provide the 
Fig. 5. Environmental outcomes of different livelihood strategies. The bars represent the mean and the lines represent the standard deviation.
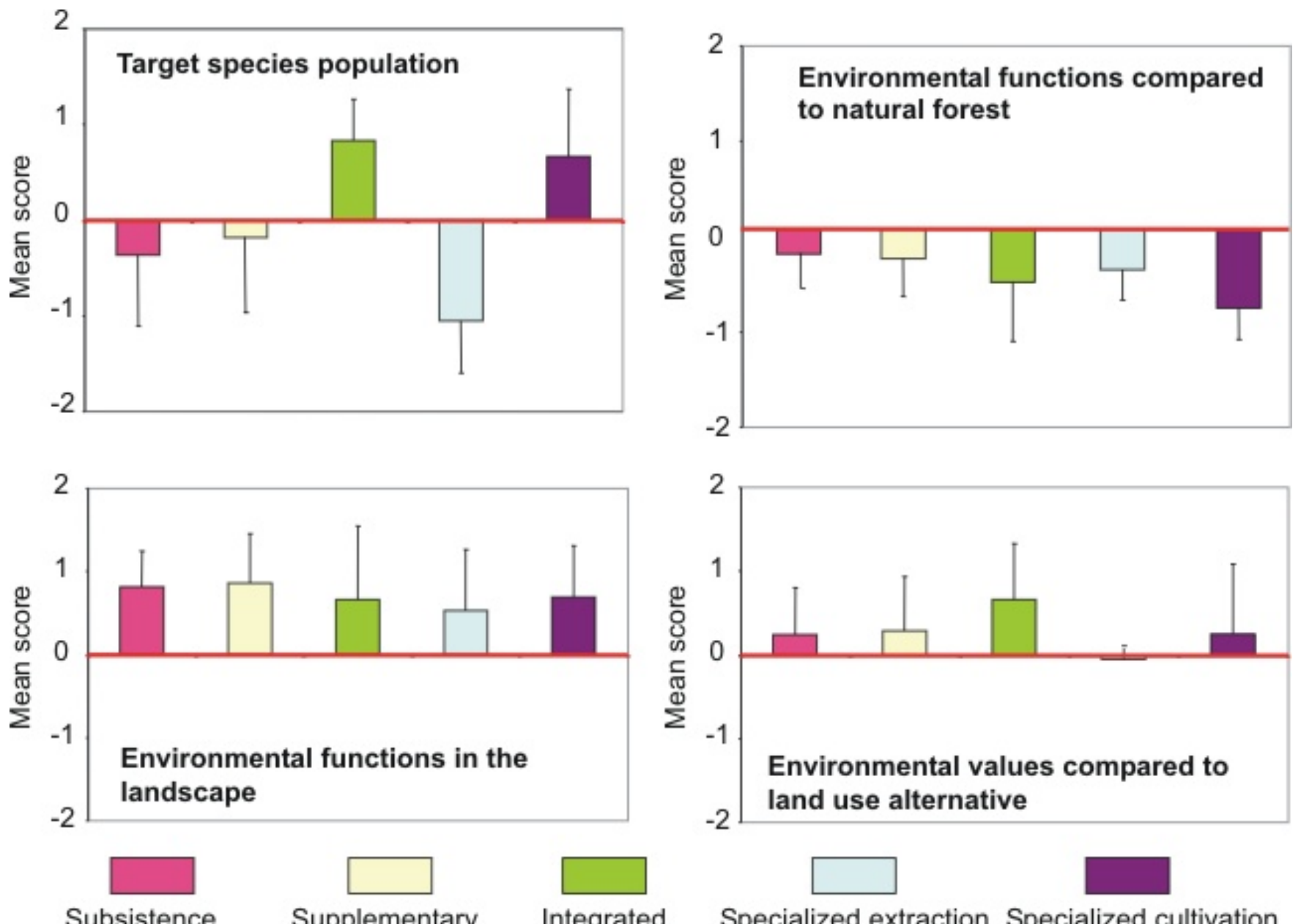

Subsistence Supplementary Integrated

Specialized extraction Specialized cultivation 
Fig. 6. The relation between household strategies, development, and conservation. The figure presents the relative relations, derived from mean scores.

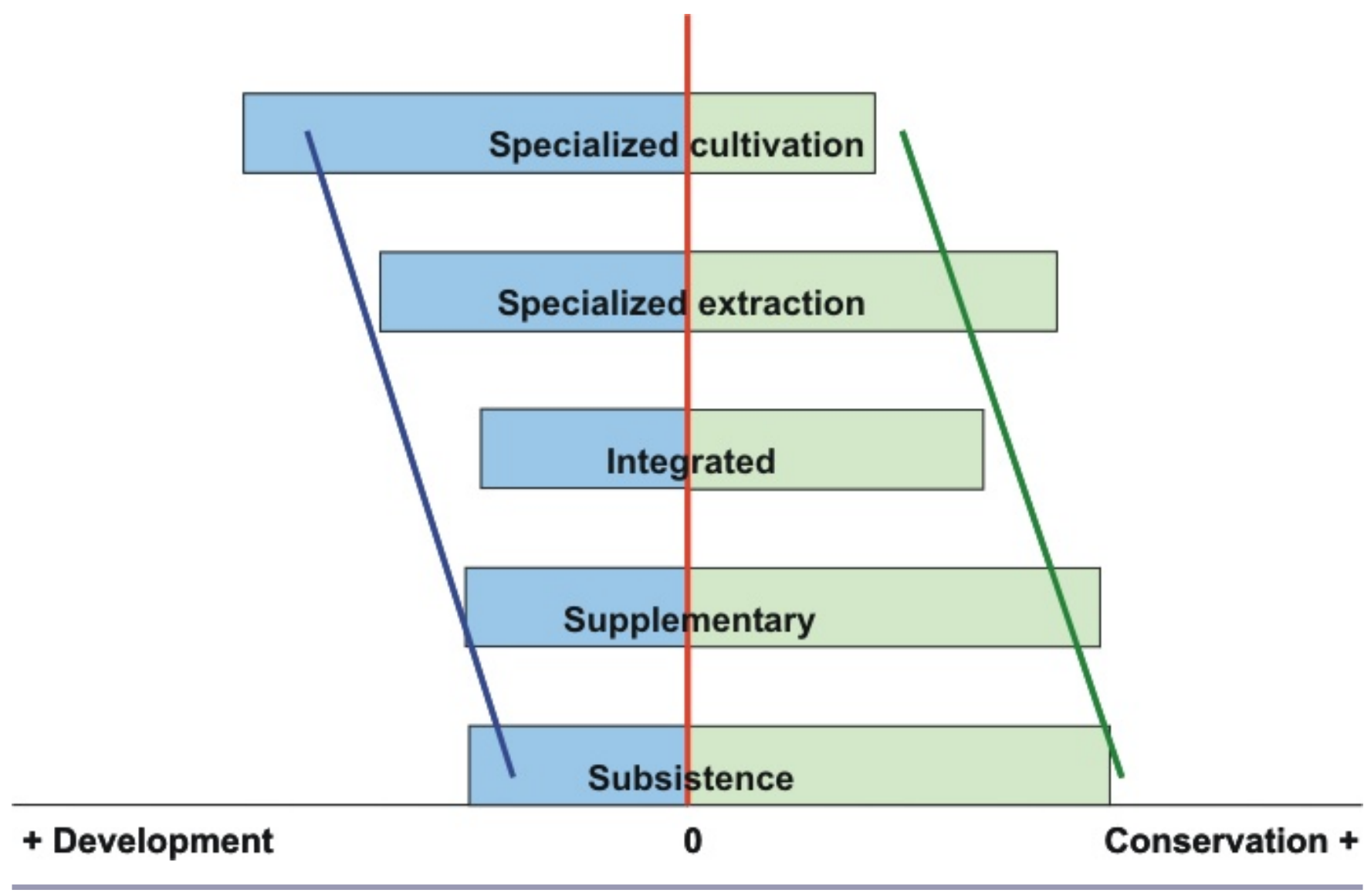

incentive or the opportunity to reinvest in the subsector. In these cases, NTFP trade is important for meeting basic needs, but there are important constraints to NTFP-based development. We speculate that many of these constraints lie outside the subsector and reflect conditions typical of the rural poor throughout the developing world. The exception is found in cases where households specialize in cultivation. These systems generate the most substantial livelihood improvements, but require a relatively high level of access to assets, such as secure tenure and market access to begin with. In most cases these conditions are not in place.

The strong correlation found between the four main sets of livelihood indicators, i.e., financial, human, physical, and social assets, also has an important methodological implication. As Angelsen and Wunder (2003) discuss, comprehensive livelihood models such as the SRL framework, are useful conceptually but difficult to use empirically. They suggest that simpler and less ambiguous indicators are more appropriate for actually measuring livelihood status and change. This is supported by the finding that financial indicators are a good proxy to measure access to human, social, and physical assets. Changes in access to natural assets and equity, however, are not related to financial assets and would need to be taken into account as independent dimensions in field-based measurement.

Unlike the livelihood outcomes, with a low occurrence of negative impacts, the environmental outcomes are highly differentiated. Environmental outcomes vary between cases and between the different scales of analysis. Furthermore, outcomes vary depending on the benchmark that is being used. Strikingly, the role of NTFP systems in the 
Fig. 7. Principle component analysis (PCA) plot of livelihood outcomes, environmental outcomes, and household strategies. The two dimensions of the PCA plot represent $96 \%$ of the data variability; the first dimension contributes $69 \%$ and the second dimension contributes $27 \%$.

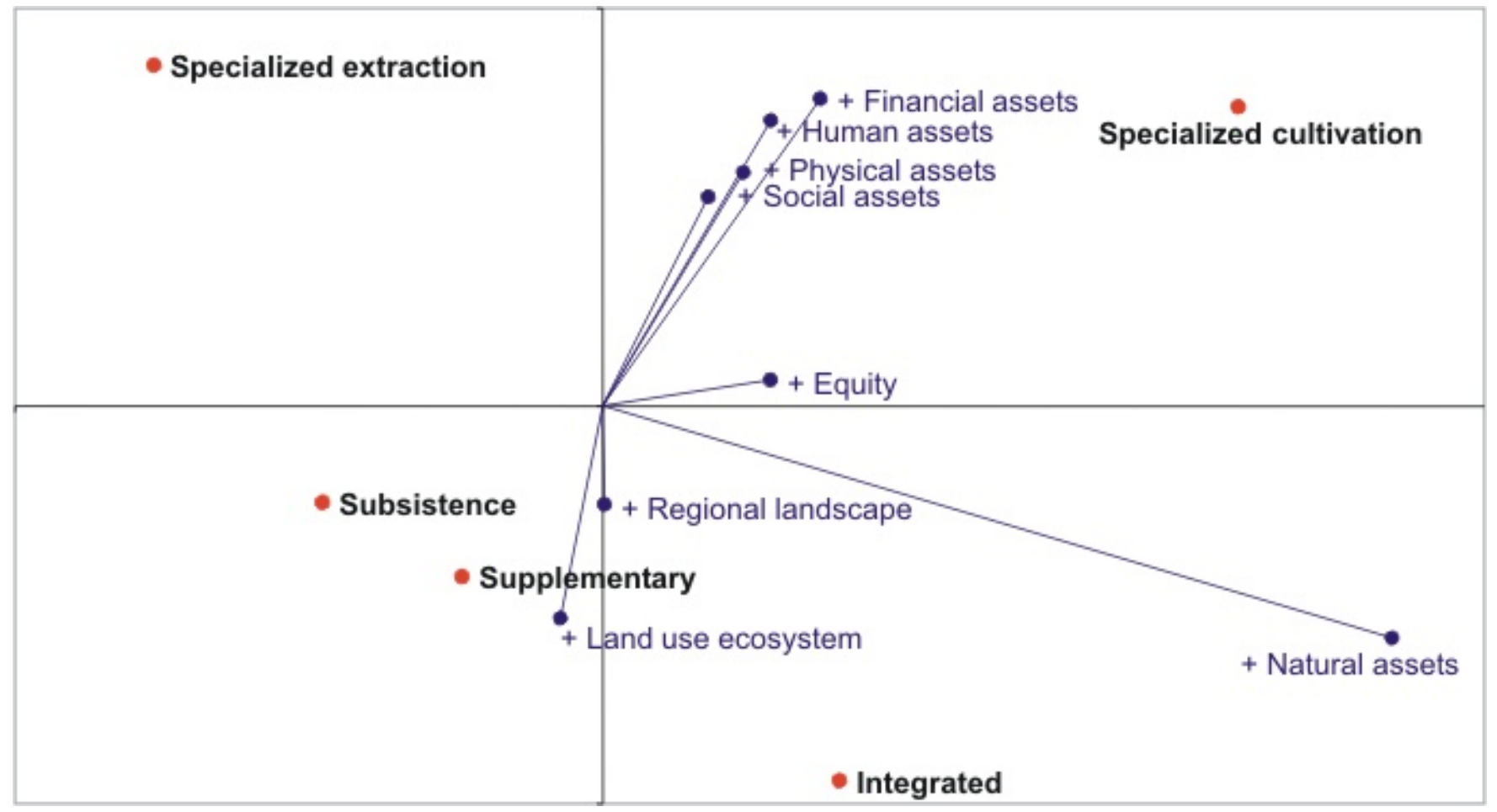

landscape is consistently positive. This helps explaining the enthusiasm with which NTFP production was promoted in conservation and development approaches as an environmentally friendly mode of production. In many landscapes, NTFP production systems provide relatively important forest functions within a matrix of more intensively managed, less environmentally functional land uses. It is likely that the common assumption of positive conservation values of NTFP commercialization uses, explicitly or implicitly, a landscape level of analysis and compares the environmental values of NTFP systems to those of the surrounding landscape.

On the basis of the cases analyzed, we conclude that commercial production of nontimber forest products is not likely to reconcile conservation and development objectives. More of the one tends to mean less of the other. We found that cases that are characterized by key variables such as secure tenure and market access are associated with high livelihood outcomes. Cases that are less developed, probably because they lack the necessary conditions to facilitate development, have higher environmental outcomes, but this is expected with less human intervention.

Efforts to achieve NTFP-based development need to create conditions that enable people to intensify forest product management and production and improve their market access. But these same conditions tend to have negative impacts on natural forests, at least at the level of the management unit. Governments and conservation and development organizations working in this area need to understand these trade-offs. Breaking away from the proposition that NTFP trade automatically reconciles conservation and development objectives will help the relevant agencies to formulate realistic objectives, and to also consider the potential negative effects of their interventions. 
Responses to this article can be read online at:

http://www.ecologyandsociety.org/vol11/iss2/art20/responses/

\section{Acknowledgments:}

We thank the 55 researchers responsible for the case studies, listed in Appendix 1, who provided the basis of the analysis presented in this paper by contributing their outcome assessments. Several people have helped to develop the outcome assessment methodology, namely, in alphabetical order: Miguel Alexiades, Carmen García, Anthony Cunningham, Hubert de Foresta, Paul Hersch Martinez, Kathrin Schreckenberg, and Sheona Shackleton. We thank Charles Clement, Tony Cunningham, Alfredo Fantini, Hubert de Foresta, Mirjam Ros-Tonen, Jeff Sayer, and Kate Schreckenberg for their valuable comments on earlier versions of this article. The four authors contributed equally to this article. The work was funded by the UK Department for International Development (DFID), the Dutch government, the European Commission (EC), the World Wide Fund for Nature UK (WWF-UK), and the Center for International Forestry Research (CIFOR).

\section{LITERATURE CITED}

Adams, W. M. 1990. Green Development: environment and sustainability in the Third World. Routledge, London, UK.

Allen, T., and T. W. Hoekstra. 1992. Towards a unified ecology. Columbia University Press, New York, New York, USA.

Angelsen, A., and S. Wunder. 2003. Exploring the forest-poverty link: key concepts, issues and research implications. Center for International Forestry Research (CIFOR) Occasional Paper 40, CIFOR, Bogor, Indonesia.

Arnold, J. E. M., and M. Ruiz-Pérez. 2001. Can non-timber forest products match tropical forest conservation and development objectives? Ecological Economics 39:437-447.

Ashley, C., and K. Hussein. 2000. Developing methodologies for livelihood impact assessment: experience of the African Wildlife Foundation in
East Africa. Working Paper 129. Overseas Development Institute, London, UK.

Bebbington, A. 1999. Capitals and capabilities: a framework for analyzing peasant viability, rural livelihoods and poverty. World Development 27:2021-2044.

Belcher, B. 1998. A production-to-consumption systems approach: lessons from the bamboo and rattan sectors in Asia. Pages 815-822 in E. Wollenberg and A. Ingles, editors. Incomes from the forest: methods for the development and conservation of forest products for local communities. Center for International Forestry Research, Bogor, Indonesia.

Belcher, B., and M. Ruiz-Pérez. 2001. An international comparison of cases of forest product development: overview, description and data requirements. Center for International Forestry Research (CIFOR) Working Paper 23. CIFOR, Bogor, Indonesia.

Belcher, B., M. Ruiz-Pérez, and R. Achdiawan. 2005. Global patterns and trends in the use and management of commercial NTFPs: Implications for livelihoods and conservation. World Development 33(9):1435-1452.

Bossel, H. 2001. Assessing viability and sustainability: a systems-based approach for deriving comprehensive indicator sets. Conservation Ecology 5(2): 12 [online] URL: http://www.consecol. org/vol5/iss2/art12/.

Campbell, B., J. A. Sayer, P. Frost, S. Vermeulen, M. Ruiz-Pérez, A. Cunningham, and R. Prabhu. 2001. Assessing the performance of natural resource systems. Conservation Ecology 5(2):22. [online] URL: http://www.consecol.org/vol5/iss2/art22/

Carney, D., editor. 1998. Sustainable rural livelihoods. What contributions can we make? Department for International Development (DFID), London, UK.

Clay, J. W., and C. R. Clement, editors. 1993. Selected species and strategies to enhance income generation from Amazonian forests. FO: Misc/93/6 Working Paper, Forestry Department, Food and Agriculture Organization, Rome, Italy. 
Cramb, R. A., T. Purcell, and T. C. S. Ho. 2004. Participatory assessment of rural livelihoods in the central highlands of Vietnam. Agricultural Systems 81(3):255-272.

Cunningham, A. 2003. Forest product trade: 6 lessons for development and conservation. Video produced by Ethnoecology Services, Fremantle, Australia.

Department for International Development (DFID). 2005. Sustainable livelihoods guidance sheets. Available online at: http://www.livelihoods. org/info/info guidancesheets.htm.

Dove, M. R. 1994. Marketing the rainforest: 'Green' panacea or red herring? Asia-Pacific Issues 13:1-7. East-West Centre, Honolulu, Hawaii.

Evans, M. I. 1993. Conservation by commercialization. Pages 815-822 in C. M. Hladik, A. Hladik, O. F. Linares, H. Pagezy, A. Semple, and M. Hadley, editors. Tropical forests, people and food: biocultural interactions and applications to development. MAB Series, Volume 13. UNESCO, Paris and Parthenon, Carnforth, UK.

Gottret, M. A. V. N., and D. White. 2001. Assessing the impact of integrated natural resource management: challenges and experiences. Conservation Ecology 5(2): 17. [online] URL: http://www.consecol. org/vol5/iss2/art17/.

Hoekstra, T. W., T. F. H. Allen, C. Flather. 1991. Implicit scaling in the choice of organism and ecological concept or when to make studies of mice and men. BioScience 41(3): 148-154.

Kusters, K., B. Belcher, M. Ruiz-Pérez, and R. Achdiawan. 2005. A method to assess the outcomes of forest product trade on livelihoods and the environment. Center for International Forestry Research (CIFOR) Working Paper 32. Available online at: http://www.cifor.org/publications/ntfpsite/ index.htm.

Levang, P., E. Dounias, and S. Sitorus. 2005. Out of the forest, out of poverty? Forests, trees and livelihoods 15(2):211-235.

Myers, N. 1988. Tropical forests: much more than stocks of wood. Journal of Tropical Ecology 4:209-221.

Nepstad, D., and S. Schwartzman, editors. 1992.
Non-timber products from tropical forests: evaluation of a conservation and development strategy. Advances in Economic Botany 9. New York Botanical Garden, New York, New York, USA.

Neumann, R. P., and E. Hirsch. 2000. Commercialisation of non-timber forest products: review and analysis of research. Center for International Forestry Research (CIFOR), Bogor, Indonesia.

Peters, C. M., A. H. Gentry, and R. O. Mendelsohn. 1989. Valuation of an Amazonian rainforest. Nature 339:655-656.

Rigby, D., D. Howlett, and P. Woodhouse. 2000. $A$ review of indicators of agricultural and rural livelihood sustainability. Sustainability Indicators for Natural Resource Management and Policy Working Paper 1. Available online at: http://les.ma n.ac.uk/ses/research/CAFRE/indicators/wp1.pdf.

Ros-Tonen, M. A. F., and K. F. Wiersum. 2005. The scope of improving rural livelihoods through non-timber forest products: an evolving research agenda. Forests, Trees and Livelihoods 15 (2):129-148.

Ros-Tonen, M. A. F., F. Zaal, and T. Dietz. 2005. Reconciling conservation goals and livelihood needs: new forest management perspectives in the 21st century. Pages 3-29 in M. A. F. Ros-Tonen, and T. Dietz, editors. African forests between nature and livelihood resources: interdisciplinary studies in conservation and forest management. Edwin Mellen, Lewiston, New York, New York, USA.

Roe, D., and J. Elliot. 2004. Meeting the MDGs: is conservation relevant? Pages 7-20 in D. Roe, editor. The Millennium Development Goals and Conservation-Managing Nature's Wealth for Society's Health. International Institute for Environment and Development (IIED), London, UK.

Ruiz-Pérez, M., and N. A. Byron. 1999. A methodology to analyse divergent case studies of non-timber forest products and their development potential. Forest Science 45(1):1-14.

Ruiz-Pérez, M., B. Belcher, R. Achdiawan, M. Alexiades, C. Aubertin, J. Caballero, B. Campbell, C. Clement, T. Cunningham, A. 
Fantini, H. de Foresta, C. García Fernández, K. H. Gautam, P. Hersch Martínez, W. de Jong, K. Kusters, M. G. Kutty, C. López, M. Fu, M. A. Martínez Alfaro, T. R. Nair, O. Ndoye, R. Ocampo, N. Rai, M. Ricker, K. Schreckenberg, S. Shackleton, P. Shanley, T. Sunderland, and Y. Youn. 2004. Markets drive the specialization strategies of forest peoples. Ecology and Society 9 (2):4. [online] URL: http://www.ecologyandsociety. org/vol9/iss2/art4/.

Stiles, D. 1994. Tribals and trade: a strategy for cultural and ecological survival. Ambio 23: 106-111.

Ticktin, T. 2004. The ecological implications of harvesting non-timber forest products. Journal of Applied Ecology 41:11-21. 


\section{Appendix 1. List of cases.}

\begin{tabular}{|c|c|c|c|c|}
\hline NoProduct & Species & $\begin{array}{l}\text { Primary use of } \\
\text { the product }\end{array}$ & Location & Authors \\
\hline 1 Kernels & Vitellaria paradoxa C.F. Gaertner & $\begin{array}{l}\text { Food (vegetable } \\
\text { fat) }\end{array}$ & Atacora, Benin & Kathrin Schreckenberg \\
\hline 2 Fuelwood & Acacia seyal Delile & Fuel wood & Far north of Cameroon & Tata precilla ijang \\
\hline $\begin{array}{l}3 \text { Medicinal } \\
\text { Bark }\end{array}$ & prunus africana (Hook. f.) Kalkman & Medicine & South West Cameroon & Nouhou Ndam \\
\hline 4 Rattan & $\begin{array}{l}\text { Laccosperma secundiflorum (p. } \\
\text { Beauv.) Kuntze }\end{array}$ & Rattan furniture & Central Cameroon & Defo Louis \\
\hline 5 Rattan & $\begin{array}{l}\text { Laccosperma secundiflorum (p. } \\
\text { Beauv.) Kuntze }\end{array}$ & Rattan handicrafts & $\begin{array}{l}\text { Rio Muni, Equatorial } \\
\text { Guinea }\end{array}$ & Terry Sunderland \\
\hline 6 Chewsticks & $\begin{array}{l}\text { Garcinia kola Heckel and Garcinia } \\
\text { epunctata Stapf }\end{array}$ & Medicine/ cosmetics & Western Ghana & Dominic Blay, Jr. \\
\hline 7 Rattan & $\begin{array}{l}\text { Eremospatha macrocarpa (G. Mann \& } \\
\text { H. Wendl.) H. Wendl. }\end{array}$ & Rattan handicrafts & Southwestern Ghana & $\begin{array}{l}\text { Charles Adu- } \\
\text { Anning }\end{array}$ \\
\hline 8 Wood & Brachylaena huillensis O. Hoffm. & Woodcarvings & Coast province, Kenya & Simon K.Choge \\
\hline 9 Root & $\begin{array}{l}\text { Harpagophytum procumbens (Burch.) } \\
\text { DC ex Meisn. }\end{array}$ & Medicine & Omaheke, Namibia & Rachel Wynberg \\
\hline 10Fruit & Garcinia Kola Heckel & Food & Ogun, Nigeria & Atilade Adebisi \\
\hline 11Fruit & Dacryodes edulis (G. Don) H.J. Lam & Food & Edo, Nigeria & Hassan G.Adewusi \\
\hline 12Bark & $\begin{array}{l}\text { Cassipourea flanaganii (Schinz) } \\
\text { Alston }\end{array}$ & Medicine & Eastern Cape, South Africa & Michelle Cocks \\
\hline 13Wood & pterocarpus angolensis DC. & Woodcarvings & Northern South Africa & Sheona Shackleton \\
\hline 14Wood & polyscias fulva (Hiern) Harms & Woodcarvings & Mpigi, Uganda & Omeja A. patrick \\
\hline $\begin{array}{l}\text { 15Elephant } \\
\text { hunting }\end{array}$ & Loxodonta africana & Sport Hunting & $\begin{array}{l}\text { Mashonaland, Central } \\
\text { Zimbabwe }\end{array}$ & Dale Dore \\
\hline 16palm Fibre & Hyphaene petersiana Mart. & palm basket & Masvingo, Zimbabwe & phosiso Sola \\
\hline 17Wood & Afzelia quanzensis Welw. & Woodcarvings & Masvingo, Zimbabwe & $\begin{array}{l}\text { Wavell Standa- } \\
\text { Gunda }\end{array}$ \\
\hline 18Bamboo & $\begin{array}{l}\text { phyllostachys heterocycla (Carrière) S. } \\
\text { Matsum. }\end{array}$ & $\begin{array}{l}\text { Bamboo mats and } \\
\text { handicrafts }\end{array}$ & Zhejiang, China & Fu Maoyi \\
\hline 19Mushroom & $\begin{array}{l}\text { tricholoma matsutake (ito \& imai) } \\
\text { Singer }\end{array}$ & Food & Yunnan, China & Chen Ying Long \\
\hline 20Cardamom & Elettaria cardamomum Maton & Spice & Kerala, india & T.K. Raghavan Nair \\
\hline
\end{tabular}




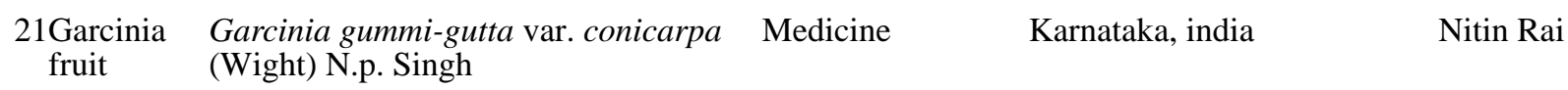

22Tendu le- Diospyros melanoxylon Roxb. aves

23Ant larvae Oecophylla smaragdina

Cigarette wrappers Madya pradesh, india

Arvind A. Boaz

24Benzoin Styrax paralleloneurum perkins

Bird food

Banten, indonesia

Nicolas Césard

incense

North Sumatra, indonesia

paints, inks and Lampung, indonesia varnishes

Rattan handicrafts East Kalimantan, indonesia Fadjar pambudi and mats

Essential oils for perfume

East Nusa Tenggara, indonesia

od

Woodcarvings

Bali, indonesia

paraserianthes falcataria (L.) i.C. Nielsen

29Wood Agathis alba (Lam.) Foxw.

30Mushroom Lentinula edodes (Berk.) pegler

31Bark Boehmeria malabarica Wedd.

32Cardamom Amomum spp.

33Mulberry Broussonetia papyrifera (L.) L'Hér. ex paper

Bark Vent.

Woodcarvings

West Java, indonesia

Food

incense

Medicine

34Fruit

Choerospondias axillaris (Roxb.) B.L. Human food Burtt \& A.W. Hill

35Rattan

Calamus spp.

36Bamboo Neohouzeaua dullooa (Gamble) A. Camus

37Cardamom Amomum villosum Lour.

38Rattan Calamus tetradactylus Hance

39Fruit Orbignya phalerata Mart.

40Fruit platonia insignis Mart.

41Fruit Bactris gasipaes Kunth

42Fruit Endopleura uchi (Huber) Cuatrec.

43Leaves
Rattan handicrafts Southern Tagalog, philippines

Bamboo handicrafts Bac Kan, Vietnam

Medicine

Bac Kan, Vietnam

Rattan handicrafts Ha Tinh, Vietnam

Oil Maranhão, Brazil

Food

Food

Food

Medicine pará, Brazil

Amazonas, Brazil

pará, Brazil

pará, Brazil
Carmen García

Fernández

Hubert de Foresta

Dede Rohadi

Dede Rohadi

pipin permadi

Youn Yeo Chang

Joost Foppes

Chaterine Aubertin

Chaterine Aubertin

Krishna H.Gautam

Honorato G.palis

An Van Bay

Dinh Van Tu

Vu Dinh Quang

Claudio pinheiro

Socorro Ferreira

Charles Clements

patricia Shanley

Walter Steenbock 


\begin{tabular}{|c|c|c|c|c|}
\hline 44Leaves & Maytenus ilicifolia (Schrad.) planch. & Medicine & paraná, Brazil & Marianne Scheffer \\
\hline 45palm Heart & Euterpe edulis Mart. & Food & São paulo, Brazil & Alfredo Fantini \\
\hline 46Root & pfaffia glomerata (Sprengel) pedersen & Medicine & paraná, Brazil & $\begin{array}{l}\text { Cirino Corrêa } \\
\text { Júnior }\end{array}$ \\
\hline 47palm Fibre & Carludovica palmata Ruiz \& pav. & panama hats & Manabí, Ecuador & $\begin{array}{l}\text { Rocío Alarcón } \\
\text { Gallegos }\end{array}$ \\
\hline 48Fruit & $\begin{array}{l}\text { pouteria sapota (Jacq.) H.E. Moore } \\
\text { and Stearn }\end{array}$ & Food & Veracruz, Mexico & Martin Ricker \\
\hline $\begin{array}{l}\text { 49Fruit (alls- } \\
\text { pice) }\end{array}$ & pimenta dioica (L.) Merr. & Spice & puebla, Mexico & $\begin{array}{l}\text { Miguel-Angel Mart- } \\
\text { ínez-Alfaro }\end{array}$ \\
\hline $\begin{array}{l}\text { 50Leaves for } \\
\text { fibre }\end{array}$ & Sabal yapa C. W"right" ex Becc. & Roofing & Quintana Roo, Mexico & Javier Caballero \\
\hline 51tree bark & trema micrantha $(\mathrm{L}$.$) Blume$ & Bark paper & puebla, Mexico & Citlalli López \\
\hline 52Wood & Bursera glabrifolia (Kunth) Engl. & Woodcarvings & Oaxaca, Mexico & Silvia E. purata \\
\hline 53Wood & $\begin{array}{l}\text { Bursera aloexylon (Schiede ex } \\
\text { Schltdl.) Engl. }\end{array}$ & Woodcarvings & puebla, Mexico & $\begin{array}{l}\text { paul Hersch- } \\
\text { Martínez }\end{array}$ \\
\hline 54Bush meat & Tayassu tajacu and Tayassu pecari & Food & Maynas, peru & $\begin{array}{l}\text { Carlos Cornejo } \\
\text { Arana }\end{array}$ \\
\hline 55Fruit & $\begin{array}{l}\text { Uncaria tomentosa (Willd. ex Roem. } \\
\text { and Schult.) DC. }\end{array}$ & Medicine & puerto inca, peru & Walter Nalvarte \\
\hline
\end{tabular}

